\title{
Bumblebees of the Azores (Apidae: Bombus)
}

\author{
Oliver E. Prŷs-Jones (10), Paul H. Williams (10) ${ }^{\mathrm{b}}$ and James C. Carolan (1) ${ }^{\mathrm{c}}$ \\ alndependent Researcher, Denbigh, UK; 'bepartment of Life Sciences, The Natural History Museum, \\ London, UK; 'Department of Biology, University of Maynooth, Maynooth, Ireland
}

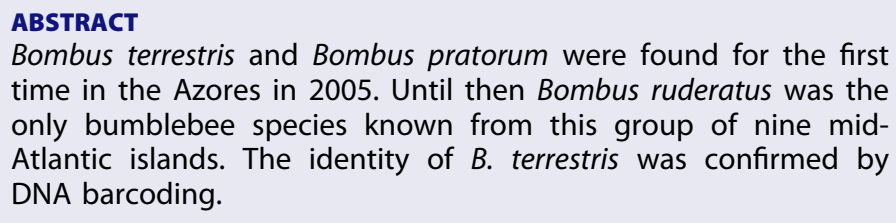
time in the Azores in 2005. Until then Bombus ruderatus was the only bumblebee species known from this group of nine midAtlantic islands. The identity of $B$. terrestris was confirmed by DNA barcoding.

\section{ARTICLE HISTORY}

Received 20 September 2017 Accepted 16 January 2018

Online 9 February 2018

\section{KEYWORDS}

Azores; anthropogenic effects; bumblebees; distribution; colonization

\section{Introduction}

The Azores archipelago is more remote from a potential source for colonization than anywhere else that bumblebees are found, with the exception of Tasmania and New Zealand. Given the potential for anthropogenic introductions from mainland Europe - unwittingly in freight and intentionally for greenhouse crop pollination - it was decided to reassess which species are now present. Bombus ruderatus was first recorded in the Azores in the midnineteenth century and until 2005 it was the only species known to occur there (Borges et al. 2005).

\section{Material and methods}

The first author visited two of the nine islands in 2005: Faial between 25 and 30 July and Pico from 30 July to 5 August (Figure 1). Bees were identified in the field when possible; some were photographed or caught for closer inspection, and a small number of specimens of each species were collected for subsequent examination. Existing specimens in the Natural History Museum (NHM), London, were examined, and reference specimens of each species collected during the present visit have been deposited in the NHM collection.

\section{Results}

Before this study, the NHM collection held 27 Azorean bumblebee specimens collected or donated between 1870 and 1971. Referring to the Azores, Godman (1870) mentions that his collection of Hymenoptera was identified by Frederick Smith of the British Museum (now the NHM), and comments that Bombus ruderatus was 'common in all the islands I visited'. The NHM accession register records five specimens of $B$. ruderatus 


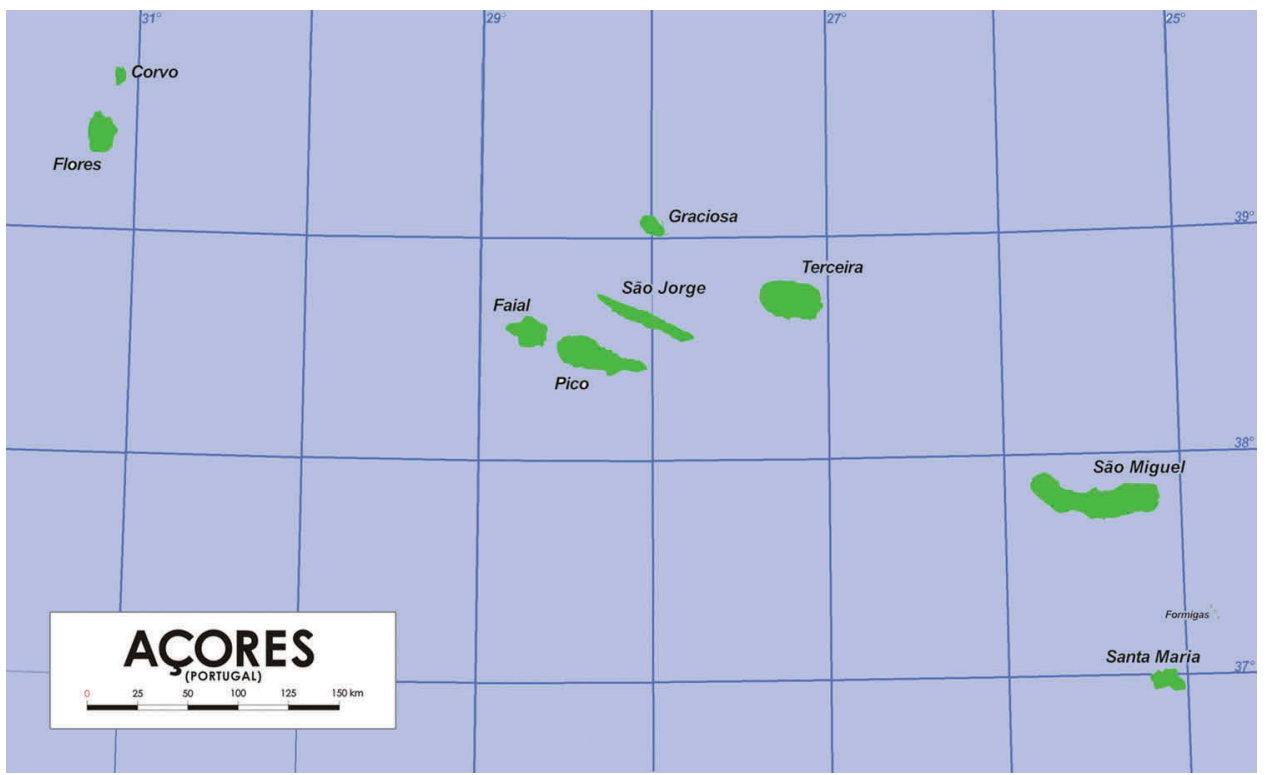

Figure 1. Islands of the Azores archipelago (Wikimedia Commons).

from Godman, but currently only three of these individuals can be located. Collected in 1865 , and donated to the museum in 1870, each specimen bears a single contemporary small, round, blue label, with an accession number on one side [70/51], and a handwritten island name on the obverse - respectively, 'Fugal' [Faial], 'St. Michael's' [São Miguel] or 'Tercira' [Terceira]. We confirm that they are all B. ruderatus.

In his travel itinerary Godman indicates that he personally visited five or six of the nine islands: the three mentioned above, together with Flores and Corvo, and perhaps Pico. His collector, Mr Brewer, was sent to find insects on 'St. Marys's' [Santa Maria], but 'obtained very few' (Godman 1870). Godman sailed via Graciosa and 'St. George's' [São Jorge] but did not land on these islands. He is not explicit about visiting Pico: 'I returned again to Flores, and left a day or two after in the same schooner for Fayal [Faial]. Here I remained some days, waiting for a favourable opportunity to ascend Pico; but though I made the attempt, the weather, unfortunately, prevented my succeeding; and with some regret at not being able to accomplish this object I finally left for Terceira' (Godman 1870, p. 15). Other specimens that he mentions, collected on Pico, imply that he may have been there (Godman 1870). On the basis that he donated a specimen of B. ruderatus from each of Faial, São Miguel and Terceira, it seems possible that the two specimens now missing from the NHM collection were from the other two islands that we know he visited (Flores and Corvo). We do not know whether Smith examined additional material that was not donated, but this may be unlikely: Godman (1870) comments (p. 99) that he 'brought home but a small number of insects of this order' [Hymenoptera]; 'my materials are almost too scanty to give any general conclusions respecting the Hymenoptera of the Azores'.

Recording sites and observations for 2005 are summarized in Table 1. Three species were found on Faial (B. ruderatus, Bombus pratorum and Bombus terrestris) and two on Pico (B. ruderatus and $B$. terrestris). Thirty specimens were collected: 14 B. ruderatus, 13 
Table 1. Sites where bumblebees were observed and specimens were collected in 2005.

\begin{tabular}{|c|c|c|c|c|c|}
\hline \multirow[b]{2}{*}{ Sites } & \multirow[b]{2}{*}{ Lat./Long. } & \multirow[b]{2}{*}{ Dates } & \multicolumn{3}{|c|}{ Bumblebee observations/specimens collected } \\
\hline & & & Bombus ruderatus & Bombus pratorum & Bombus terrestris \\
\hline \multicolumn{6}{|l|}{ Faial } \\
\hline Garden, Cedros & $38.628,-28.692$ & $25-29.07$ & QWM++/4ఫ30" & & \\
\hline Roadside verge, near Caldeira & $38.570,-28.673$ & 26.07 & & WM++/20" & \\
\hline Caldeira rim (herb flora) & $38.580,-28.712$ & 26.07 & WM+/1 ఢ & QWM++/3 ఫ20" & \\
\hline Garden, Ponta dos Capelinhos & $38.593,-28.814$ & 28.07 & $1 \mathrm{~W}$ & & \\
\hline Lavada, Castelhano (herb flora) & $38.602,-28.712$ & 29.07 & & $\mathrm{WM}++/ 2 \varnothing 40^{\prime \prime}$ & \\
\hline Cabeço da Fonte (native scrub) & $38.593,-28.799$ & 29.07 & & & $1 \mathrm{M} / 10^{* *}$ \\
\hline Roadside verge, Praia do Norte & $38.607,-28.751$ & 29.07 & QWM++/1Q & & \\
\hline \multicolumn{6}{|c|}{ Pico } \\
\hline Garden, São Vicente & $38.547,-28.368$ & 30.07 & $1 \mathrm{~W}$ & & \\
\hline Verge/scrub (road EN2) & $38.494,-28.288$ & 03.08 & $W M++/ 2 \varnothing 10^{\prime \prime}$ & & \\
\hline Verge/scrub (road EN3) & $38.483,-28.323$ & 03.08 & $\mathrm{WM}++/ 1 \Varangle$ & & 2W/1ఢ \\
\hline Roadside scrub/woodland & $38.530,-28.388$ & 04.08 & WM+ & & $1 \mathrm{M} / 1 \mathrm{O}^{* *}$ \\
\hline Roadside scrub/woodland & $38.520,-28.391$ & 04.08 & $1 \mathrm{M} / 10^{\prime \prime}$ & & \\
\hline
\end{tabular}

Observations of queens (Q); workers (W); males (M). Collected specimens: queen (Q); worker (†); male ( $\left.\sigma^{7}\right)$. Abundance: a few individuals $(+)$; numbers of individuals $(++) ;{ }^{*}$ indicates that identification was confirmed by DNA barcoding.

Table 2. Plants on which bumblebees were observed foraging.

\begin{tabular}{lccc}
\hline Species & Bombus ruderatus & Bombus pratorum & Bombus terrestris \\
\hline Fuschia sp. & + & & \\
Crocosmia sp. & + & & \\
Hedychium gardnerianum & + & + & + \\
Prunella vulgaris & + & & + \\
Rubus sp. & + & & \\
Cirsium sp. & + & & \\
\hline
\end{tabular}

B. pratorum and 3 B. terrestris (Table 1). Fragments of the cytochrome oxidase subunit I gene of individual specimens of $B$. terrestris from Faial and Pico were sequenced to confirm the species identification (mentioned in Williams et al. 2012).

Bombus ruderatus was the most frequently observed and widely distributed species on both Pico and Faial, visiting both introduced and native flowers (Table 2), particularly those with long corolla tubes accessible with its long tongue. Bombus pratorum was only observed on the island of Faial, in spite of a careful search for it on Pico. Bombus terrestris was present on both islands, but seen infrequently; the impression was that it was not common at that time. All three species were seen to forage on Prunella vulgaris (self-heal), which was common on lightly grazed land and roadside verges.

\section{Discussion}

So far as we are aware, these observations from 2005 are the first records for B. pratorum and $B$. terrestris from the Azores. Bombus terrestris has subsequently been found on all nine islands in the archipelago, while B. pratorum appears, at present, to remain restricted to the island of Faial (Weissman et al. 2017). Weissman et al. (2017) comment that B. pratorum 'will perhaps not establish a permanent population and disappear after a few years'. Their view was based on the only record then available (http://www.inaturalist.org/observations/1910834). Our observations pre-date this record by 10 years; in 2005, the species was common on the slopes of the Caldeira that dominates Faial. Its status seemed secure, but this will need to be 
Table 3. Distances between islands $(\mathrm{km})$ in the Azores archipelago: direct and 'longest-leg' indirect routes (the latter in brackets).

\begin{tabular}{|c|c|c|c|c|c|c|c|c|}
\hline & Corvo & Graciosa & Terceira & São Jorge & Pico & Faial & São Miguel & Santa Maria \\
\hline Flores & 18 & 267 (220) & 334 (220) & 255 (220) & $246(220)$ & 220 & $490(220)$ & $589(220)$ \\
\hline Corvo & & $270(220)$ & 337 & $262(220)$ & $256(220)$ & $230(220)$ & 499 (220) & 599 (220) \\
\hline Graciosa & & & 57 & 37 & 62 & 68 (37) & 227 (139) & 333 (139) \\
\hline Terceira & & & & 38 & 67 & 108 (38) & 139 & 249 (139) \\
\hline São Jorge & & & & & 18 & 31 & 184 (139) & 287 (139) \\
\hline Pico & & & & & & 6 & 201 (139) & 298 (139) \\
\hline Faial & & & & & & & 254 (139) & 350 (139) \\
\hline São Miguel & & & & & & & & 81 \\
\hline
\end{tabular}

Bold type indicates distances $<100 \mathrm{~km}$ (estimated unassisted maximum dispersal distance of a queen bumblebee [see Prŷs-Jones et al. 2016]).

confirmed by further observations. If so, it is likely B. pratorum will spread to Pico by natural or human-mediated dispersal, as Faial and Pico are only $6 \mathrm{~km}$ apart.

Godman (1870) found B. ruderatus to be common on the islands he visited. The Azores archipelago is a great distance from other landmasses (847 km northwest of Madeira, $1120 \mathrm{~km}$ northwest of the Canaries, and about $1934 \mathrm{~km}$ southeast of Newfoundland, Canada), and at least $1382 \mathrm{~km}$ west of Portugal, which supports the nearest known continental population of this species (B. ruderatus is found on Madeira and, since 2005, also on the Canary Islands [Pérez and Macías-Hernández 2012]). The inevitable conclusion is that $B$. ruderatus hitchhiked to the Azores with man, probably sometime after settlement in the fifteenth century.

Lack of genetic differentiation of Azores specimens of $B$. terrestris from those of mainland Europe (Weissman et al. 2017), together with the finding that $B$. terrestris is now present on all nine islands, some of which are widely dispersed (Table 3 ), suggests deliberate and recent importation, probably for crop pollination (e.g. greenhouse tomatoes).

Bombus terrestris appeared to be uncommon on both Pico and Faial during our visit, which might be consistent with recent establishment. Two of the main commercial companies supplying bumblebee colonies for export are Koppert and Biobest. Koppert answered a request for information by telling us that they have never directly exported bumblebee colonies to the Azores; Biobest did not respond. Of course, without specific regulations to prevent it, there is nothing to stop individuals or intermediary companies importing colonies from any producer. Examination of further museum and photographic collections, and enquiries on the islands (particularly with commercial vegetable producers) may help to establish with greater certainty when colonization by B. terrestris (and B. pratorum) occurred.

Where there is no history of prior connection to a continental landmass, it is almost inevitable that remote islands that host bumblebee species do so because of human agency at some point in their history (see Prŷs-Jones et al. 2016). Monitoring the bumblebee fauna of the Azores archipelago will probably reveal continuing instances of species arriving by virtue of man's activities, both inadvertent and intentional.

\section{Acknowledgements}

We are grateful to Dr Robert Prŷs-Jones for checking archived NHM correspondence relating to Godman's specimens. 


\section{Disclosure statement}

No potential conflict of interest was reported by the authors.

\section{ORCID}

Oliver E. Prŷs-Jones (D) http://orcid.org/0000-0002-1045-0422

Paul H. Williams (1) http://orcid.org/0000-0002-6996-5682

James C. Carolan (D) http://orcid.org/0000-0001-5092-674X

\section{References}

Borges PAV, Vieira V, Dinis F, Jarroca S, Aguiar C, Amaral J, Aarvik L, Ashmole P, Ashmole M, Amorim IR, et al. 2005. List of arthropods (Arthropoda). In: Borges PAV, Cunha R, Gabriel R, Martins AMF, Silva L, Vieira V, editors. A list of the terrestrial fauna (Mollusca and Arthropoda) and flora (Bryophyta, Pteridophyta and Spermatophyta) from the Azores. Horta (Angra do Heroísmo and Ponta Delgada): Direcção Regional de Ambiente and Universidade dos Açores; p. 163-221. http://hdl.handle.net/10400.3/1989.

Godman FDC. 1870. Natural history of the Azores, or Western Islands. London: John Van Voorst; p. 377.

Pérez AJ, Macías-Hernández N. 2012. Presencia de Bombus (Megabombus) ruderatus en Canarias. Revista de la Academia Canaria de Ciencias. 24:103-114.

Prŷs-Jones OE, Kristjánsson K, Ólafsson E. 2016. Hitchhiking with the Vikings? The anthropogenic bumblebee fauna of Iceland - past and present. J Nat Hist. 50(45-46):2895-2916.

Weissman JA, Picanço A, Borges PAV, Schaefer H. 2017. Bees of the Azores: an annotated checklist (Apidae, Hymenoptera). ZooKeys. 642:63-95.

Williams PH, Brown MJF, Carolan JC, Goulson D, An J, Aytekin AM, Best LR, Byvaltsev AM, Cederberg B, Dawson R, et al. 2012. Unveiling cryptic species of the bumblebee subgenus Bombus s. str. world-wide with COI barcodes (Hymenoptera: apidae). Syst Biodivers. 10:21-56. 
Copyright of Journal of Natural History is the property of Taylor \& Francis Ltd and its content may not be copied or emailed to multiple sites or posted to a listserv without the copyright holder's express written permission. However, users may print, download, or email articles for individual use. 